\title{
Ethical consideration in the reportage of sexual abuse of children: A review of selected Nigerian newspapers
}

\author{
Ben-Collins Emeka Ndinojuo \\ Department of Linguistics and Communication Studies, \\ University of Port Harcourt \\ Port Harcourt, Nigeria \\ ben.ndinojuo@uniport.edu.ng
}

\begin{abstract}
Ethical considerations are important for journalists when reporting about the sexual abuse of children. The codes of ethics of society of professional journalists and Nigeria Press Council both recognize the need for ethics when reporting abuse stories due to the sensitive nature of the subject in relation to children and minors. This paper is hinged on the social responsibility theory of the press which states that granted the media may is free to publish especially in democracies, they must, however, exercise some restraint and responsibility in the type of information they make public. Using a qualitative content analysis, 10 newspaper articles were content analyzed, 5 each from Premium Times and Vanguard newspapers between September 1, 2017, and March 31, 2018 to ascertain their level of compliance with the ethics code. The study found out that although the newspapers did not disclose the names of abuse victims, it did however; include some information in some of the stories that makes it easy for the accused to be identified. Journalists are therefore enjoined to observe the code of ethics strictly as the future lives of children could be affected.
\end{abstract}

Keywords-ethics; sexual assault; children; Nigeria; newspapers

\section{INTRODUCTION}

The media is generally regarded as the Fourth Estate of the realm saddled with the traditional responsibility of the watchdog of the society. Their surveillance function includes reporting on issues they consider of public interest. Dominick [1] classifies this surveillance function into two classes namely the "warning or beware function and the instrumental function. The former include media coverage about impending threats such as adverse weather conditions, worsening economic conditions, impending military attacks etc., while the latter include cases when the media provide information that is useful to the society and helpful in everyday activities. This research is concerned with the instrumental function of the media, specifically looking at the information newspapers include when reporting about cases of sexual abuse of children. The emphasis is to identify whether the media include information that can easily make the public identify children that have been sexually abused in newspaper reports.
Scholars are of the view that sexual assault of children is a global phenomenon that cuts across all societies of the world [2], [3]. It includes but may not be limited to sexual molestation, violation or exploitation, which could involve penetration, physical harm, non-verbal expressions such as indecent exposure, display of pornography etc. which the victim considers unpleasant. Thus, it becomes a media responsibility to report such cases to raise awareness of such antisocial behaviours; this raises the possibility of better debates which could lead to stricter legislature by policy makers in abating such societal ills. Perpetrators of sexual assault have been found not to discriminate in the gender of their victims; Isely and Gehrenbeck-Shim [4] aver that both males and females are affected but other studies have shown that the number of female sexual assault victims is far greater than male victims and the perpetrators are mainly male. Holmes and Slap [5] opine that victims of female offenders of sexual assault may be of male or female gender including children, adolescents and adults; the perpetrators regardless of their agenda are motivated by a common agenda: the power to manipulate and control the victims.

The statistics for sexual violence against children is alarming, research has shown that one in four girls and one in six boys will be sexually abused before their 18th birthday [6], $34 \%$ of people who sexually abuse a child are family members, $34 \%$ of people who sexually abuse a child are family members [7], $12.3 \%$ of women were age 10 or younger at the time of their first assault, while $30 \%$ of women were between the ages of 11 and 17 while $27.8 \%$ of the men were age 10 or younger at the time of their first assault [8]. It was also discerned that $96 \%$ of people who sexually abuse children are male, and $76.8 \%$ of people who sexually abuse children are adults [7]. These statistics are in USA, Falade and Fasuan (2017), Omoniyi [9], Ishola, [10], Odeh [11] all hint of the prevalence of sexual violence against children (especially little girls) in the Nigerian society with newspapers regularly reporting cases of sexual assault against children. Yakassai [12] citing Okunade (1998) states that a survey of Nigeria dailies pinpointed 100 cases of sexual assault against children between 2 and 16 years of age. The victims were 94 girls and 6 boys while the perpetrators age ranged from 13 to 60 years. Adedoyin and 
Adegoke [13] found that 50\% of girls who go into prostitution attribute it to sexual abuse that first occurred before their 18th birthday. Omoniyi [9] advocates that the government, civil society organisations, human rights groups, and religious bodies should work together in the efforts to combat the menace.

In as much as it is important journalists report accurately accounts of news involving sexual assault on minors, including information such as the names and addresses of the victims will not be of significance to the readers, rather, it brings the victims to limelight which may further expose them to ridicule, bullying and more abuse [14]. Jones, Finkelhor and Beckwith [15] state that media publicity is more likely to have a negative effect on child abuse victims as children have the capacity for feelings of indignity and humiliation as early as 3 or 4 years old and studies have shown that by the age of 10 , children can feel ashamed just by being presumptuous that others around them are judging them negatively [16], [17]. Experts in the field of child abuse observe that children may be more likely to develop shame in the aftermath of harrowing experiences because of their still developing self-perception [18], hence the need for some form of self-censorship by journalists and media organisations especially with information that identifies the victims of sexual assaults directly; summed up as part of ethical guidelines for journalists to follow while covering cases of sexual abuse of children.

Jones, Finkelhor and Beckwith [15] add further that sexually assaulted children need to be able to trust the protection of their privacy by those whom they confide in as much as possible. Any perceived deviation from the child's expected behaviour from the confidant heightens the risk distress, and this perception reduces the likelihood that more victims will come forward with their experiences. Victims are very disturbed about the possibility that their concealed trauma becomes information for public consumption. Finkelhor [19] assert that about half of the parents of sexual assault victims did not report their child's abuse to the police, and among the non-reporting parents, 45 percent cite the opinion friends or neighbors should they find out. Ullman [20] states that although children are most probably unaware of the probability of media attention, however, their hesitation to disclose abuse can be traced in part to apprehension over who will find out and their reaction after they find out. The apprehension of the victims of sexual abuse is in part the reason for the introduction of ethics in journalism when reporting about sexual abuse of minors. The codes of ethics of society of professional journalists and Nigeria Press Council both recognize the need for ethical consideration when reporting abuse of minor due to the sensitive nature of the subject especially for the victims and their families.

This research is hinged on the professional ethics of journalism. Scholarship in ethics of any profession involves the study of human actions with regard to their being right or wrong. Ethics is a branch of philosophy that involves systematizing, defending and recommending concepts of right and wrong conduct, often addressing disputes of moral mixture [21]. Ethics of journalism investigates ethical principles and moral problems that arise in the course of news reporting. It is applicable in all facets of journalism and is relevant to the conduct of individual journalists and newspaper organizations, in this case, reporting about the sexual abuse of children. Duru [22] states that ethics are important in journalism because they propose acceptable codes of professional conduct and with the proliferation of the internet where everyone can be a news source, the study of ethics of journalism should be central in media studies [22]. The code of ethics as prescribed by the Nigeria Press Council [23] recognizes the importance of accuracy and fairness in news reports and at the same time advises the need for privacy of individuals and their families unless the case is of public interest. It specifically refrains journalists and news organisations alike from identifying, either by name or picture, or interview children under the age of 16 who are involved in cases of sexual offences, crimes and rituals or witchcraft either as victims, witnesses or defendants.

The media community is clearly aware of the potential harm for victims in disclosing their identity when reporting on sexual abuse against children. Commentaries on the ethics of crime reporting and being sensitive to crime victims' needs and concerns have increased over recent decades [24], [25]. The issue of addressing the right of victims' to privacy has been documented (Cote \& Simpson, 2000), and ethical codes and guidelines have been written to increase journalists' sensitivity in these cases and to serve as guideline for journalists' when writing news stories of sexual abuse of children. Winch [26] recognized the need for privacy of sexually abused victims in a survey about the topic. $10 \%$ of newspaper editors surveyed for the research agree that the names of victims should never be printed, $40 \%$ thought names may be printed but only with the express permission of the victims, while $44 \%$ said names should only be printed in exceptional cases. Being that our subjects in this study are mainly children who may be unable to understand the enormity of what they have been exposed to, it is fair to assume that their names and other identifying information should never be printed when reporting on such cases in the media, and this guidelines have been provided by the Nigeria Press Council.

Nigeria Press Council and the Nigerian Union of Journalists recognize that ethics violations by journalists have been a recurrent problem that has endlessly plagued media practice in Nigeria and the world in general. Nigeria today is the nonobservance of ethics by journalists in the course of their profession. The aftereffect of this has led to dwindling performance and credibility crises among media organisations in Nigeria as already pointed out by Duru [22]. Happing further, Utor [27] restates that the mass media organisations in Nigeria have lost to a great percentage of their audience because of eroded and eroding credibility of media professionals. Efforts have been put in place to restore the credibility in mass media with the creation of several regulatory bodies such as the Nigerian Press Council (NPC), the National Broadcasting Commission (NBC). In a bid to reverse this trend, a more comprehensive code of ethics for journalists was formulated in 1998 by the Nigeria Press Organisation (NPO), comprising of the Nigeria Press Council (NPC), Nigeria Guild of Editors (NGE), Newspapers Proprietors of Nigeria (NPAN), and the Nigerian Union of Journalists (NUJ). The code was to guide journalists on the ethics of responsible journalism [28]. Tsegyu and Asemah [29] 
inform that journalists have continued however, to flout the codes without care for the consequences.

\section{RESEARCH PROBLEM}

The NPC code of ethics for journalists in Nigeria was seen as part of the effort made by regulatory bodies in Nigeria to protect child victims' identities. The current study examined the degree that personal identifying information is revealed in current journalistic practice when reporting on sexual abuse of children in Nigerian newspapers. Through the sampling and coding of selected sample of newspaper articles reporting on the sexual abuse of children, we examined how often and under which circumstances potentially identifying information about victims was published. The following research questions were raised to purposely guide the study:

- Do Nigerian newspapers provide the names of sexually assaulted children in their reports?

- Do Nigerian newspapers include the addresses of sexually assaulted children in their reports?

- Do journalists reporting about sexual assault against children include information about their school, church or mosque?

- Are the full names of the family member(s) of the victim mentioned in news reports?

- Is the offender related to the victim by family?

- Do the reports contain any information for victims, family members or the general public on available support for sexual abuse victims?

The study will be beneficial to journalists writing on sexual abuse of children as it helps professionals to reorient themselves with ethical values of the journalism profession. The study can also serve as literature and reference material for future researchers in the field of media studies.

\section{THEORETICAL FRAMEWORK}

The social responsibility theory was adopted as the theory underpinning this research. The theory had its origins from the Hutchins Commission of 1947 and has as one of its basic postulations that freedom comes with a corresponding obligation. Tsegyu and Asemah [29] notes that the social responsibility theory was proffered as an improvement on the shortcomings of the libertarian theory. The theory believes that with freedom comes a concomitant responsibility. In other words, the theory serves as a means of calling the press to order, especially as it was beginning to abuse the unrestrained freedom the libertarian theory afforded it. Ojobor [30] suggested that the social responsibility theory advocates that the media should regulate itself within the framework of law and established institutions in the society to be able to carry out its responsibilities. This self-regulation is observed in regulatory bodies that try to streamline the activities of journalists to fit into an acceptable standard and is best seen in the code of ethics for Nigerian journalists developed by NPC in conjunction with NUJ, NPAN and NGE.

\section{MethodOLOGY}

The research was a qualitative content analysis of two Nigerian newspapers, Vanguard and Premium Times. The study looked at newspaper content with news stories about the sexual abuse of children with emphasis on investigating the extent to which journalists apply the ethics of not including information capable of identifying child victims of sexual abuse in news reports as well as information on how victims can be supported by the relevant government agencies and Non-Governmental organisations (NGOs). The two newspapers were selected as representatives of national newspapers because of their circulation and readership; Vanguard is rated as the most widely read newspaper in Nigeria, while Premium Times is the most read internet newspaper in Nigeria (Alexa, 2017). The sample population consisted of 10 purposively selected news stories about sexual abuse of children between September 2017 and March 2018 from the two selected newspapers. The results were descriptively analyzed using discourse analysis.

\section{FINDINGS AND DISCUSSIONS}

The research findings are presented and discussed for each of the selected newspapers.

\section{A. Vanguard results}

The results from the content analysis of 5 news reports from the Vanguard newspaper revealed that none of the 5 stories analyzed revealed the identity of children who were sexual assault victims in adherence to the code of ethics as prescribe by NPC that states that " a journalist should not identify, either by name or picture, or interview children under the age of 16 who are involved in cases concerning sexual offences, crimes and rituals or witchcraft either as victims, witnesses or defendants." Vanguard news reports identify assaulted children as "victim" in each of their news stories cited.

In terms of stating the victims' addresses, the Vanguard included the addresses of the victims mentioned in two of the cited stories, making it possible to trace the identity of the victims by people in their locality. In one of the cases, the victim was abused by her Father, and in the other case, the victim was tragically abused by her neighbour and eventually lost her life in the process. Including the addresses has the potential to expose the family members to further abuse and ridicule by members of the public and their peer groups [14], [15], [16]. The newspaper should have done more by excluding such information as its exclusion would not have affected the substance of the story as was shown in the 3 other stories that did not contain the address of the victims'. This was seen better in the third research objective where Vanguard avoided the use of information that identifies the schools, church or mosque the victims even though some of the acts were alleged to occur around the school environment.

The newspaper goes further to identify the names of the fathers' of two of the victims which also increases the potential of identifying the victims and their family members by the public increase the possibility of more negative effects [18]. This may not have been necessary as three other stories were 
written without information identifying the family members of the victims. In one of the cases, the victim's father was the perpetrator and in the other story, the father was identified by name as the complainant. Both instances were avoidable as naming the fathers exposes other family members to further abuse and ridicule in addition to the abuse that has already happened. In two of the stories, the offenders were identified as relatives of the abused children, the father in one case and a relative of the wife of the accused perpetrator in the other case.

The newspaper does not include any information about how victims or their family can contact government agencies or NGOs for support in cases of sexual assault against children. This should have been done as part of corporate social responsibility on the part of the newspaper as victims of sexual assault go through a lot mentally, physically, and psychologically in the dealing with the after effects of sexual abuse. With the resources at the disposal of these news organisations, it would be a step in the right direction to provide information of how and where victims and family can receive support and in cases where the government is derelicting in its duties, they can be held accountable to account for resources budgeted for such cases.

\section{B. Premium Times results}

In line with the ethics code of NPC that prescribes identifying children who have been sexually abused in news reports, Premium Times also avoids naming the sexually abused children. They use names such as "Child X”, "victim”, "girl", "child", and also including the clarification that the name of the victim is withheld, showing that they are aware of the ethics of not including the victim's name in the story. From the results, Nigerian newspapers understand the ethics of not naming children who have been sexually assaulted so as not to expose them and their family to further abuse or victim shaming.

In terms of other related information such as the address of the victims, the addresses were not included in all but one story among those cited by Premium Times where the victim was identified as "Child X". The particular case is peculiar as the perpetrator was reported to the mother of the victim by his own daughter who made the discovery and from there the case was reported to the police. Initially, the child was apprehensive in opening up to the mother as the accused told her she will die if she told anyone about what they do together. Ullman [20] pointed this out when he mentions that children are apprehensive about who will find out and what the consequences will be. In this case, the assumed consequence by the child was death, and the story goes on to state that on noticing that nothing of such was happening, the child was motivated to say more and her narrative revealed more horrific abuse each time she's asked to narrate her ordeal with the accused.

Information about the school the victims attended was mentioned in two of the reports. They may have been mentioned because the alleged offenses occurred on the school premises during school hours, when the parents placed the children in the care of the school management. Naming the school has its merits and demerits, the merit is that it warns other parents about the negligence and lapses on the part of the school management to protect minors in their care. In one of the instances, the mother was virtually bullied by the school management and was seen as a troublemaker trying to tarnish the reputation of the school. But for the persistence of the mother, the case would have been swept aside and the perpetrator free to continue abusing other kids as the management took the inappropriate step of transferring the accused to another branch of their school instead of outrightly terminating his appointment or the lesser punishment of suspending him pending the outcome of investigations to ensure he is not left unsupervised with other children. In the other instance, the school was mentioned only because the school premises was where the alleged offence occurred, there was no mention of disciplinary measures against the accused, however, he had absconded and jumped bail and has been nowhere to be found.

The paper did right by not mentioning the name of the victim's mother; they could also have gone a step further by not including the address of the victim as it did not add substance to the story and its exclusion in the other stories did not diminish the veracity of the information they put out in the other four sexual assault stories analyzed. Premium Times also did not identify the names of any of the victims' family in their reports thus providing another layer of anonymity for the victims as prescribed by the NPC code. Further analysis revealed that none of the identified perpetrators by the newspaper was related to the victim. Like Vanguard, the newspaper did not provide any information that directs victims' and family members' relevant government agencies and NGOs they can contact for support.

\section{CONCLUSION}

Overall, we can say that both newspapers did not identify child victims of sexual assaults by their names as prescribed by the Nigerian Press Council. Premium Times however, provided less supplementary information that can identify children who were victims of sexual abuse compared to Vanguard newspaper. Media organisations should understand that with power comes responsibility, and the press can help in so many ways, not just by bringing such stories to light, but by also ensuring that victims and their families have access to as much information as possible to help them deal with the trauma and tragedy that accompany such cases. Identifying government agencies and NGOs that provide legal, moral, emotional and psychological support can also ensure that the perpetrators receive the just punishment commensurate to the crime and the victim and their families are rehabilitated to avoid adding them to the many negative statistics accompanied with children exposed to abuse. The study recommends that the study be replicated with a larger number of newspapers and sample size in order to better generalize the findings across the mediascape in Nigeria. 


\section{REFERENCES}

[1] J. R. Dominick, Dynamics of mass communication: Media in the digital age, 7th ed., .New York: McGraw-Hill, 2002.

[2] U. O. Eze, "Prevention of sexual assault in Nigeria," Ann. of Ibadan Postgrad. Medic., vol. 11, no. 2, pp. 65-70, 2013.

[3] G. C. Egbo, "An evaluation of newspaper coverage of sexual violence against women and children in selected Nigerian newspapers," Thesis, Dept. Mass Commun., Nnamdi Azikiwe Univ., Awka, Nigeria, 2012.

[4] P. J. Isely, and D. Gehrenbeck-Shim, "Sexual assault of men in the community,” J. of Commun. Psychol., vol. 25, no. 2, pp. 159-166, 1997.

[5] W. Holmes and G. Slap, "Sexual abuse of boys. Definition, prevalence, correlate, sequelae, and management," J. of the American Medic. Assoc., vol. 280, no. 21, pp. 1855-62, 1998.

[6] D. Finkelhor, G. Hotaling, I. A. Lewis, and C. Smith, "Sexual abuse in national survey of adult men and women: Prevalence, characteristics and risk factors,” Chi. Ab. \& Negl., vol. 14, pp. 19-28, 1990. doi: 10.1016/0145-2134(90)90077-7.

[7] National Sexual Violence Resource Center, "Child sexual abuse prevention: Overview,” 2011. [Online]. Available: http://www.nsvrc.org/sites/default/files/Publications_NSVRC_Overview Child-sexual-abuse-prevention_0.pdf

[8] M. C. Black, K. C. Basile, M. J. Breiding, S. G. Smith, M. L. Walters, M. T. Merrick, and M. R. Stevens, "The National Intimate Partner and Sexual Violence Survey: 2010 summary report,” 2011. [Online]. Available: http://www.cdc.gov/ViolencePrevention/pdf/NISVS_Report2010-a.pdf

[9] M. E. Omoniyi, "Rape endemic in Nigeria: Causes, effect and probable way out,” Global J. of Human-Social Sci.: H Interdisc., vol. 17, no. 2, pp. 1-6, 2017.

[10] S. A. Ishola, "Domestic Violence: The Nigerian Experience,” Asia-Afr. J. of Miss. and Minis., vol. 13, pp. 3-16, 2016.

[11] J. C. Odeh, "Moral decadence among Catholic youths in Abakaliki Diocese,” Unpublished thesis, Ebonyi State Univ., Nigeria, 2013.

[12] U. M. Yakassai, "A silent weapon on girls/women and a devastating factor on their education,” Int. J. of Edu. and Eval., vol. 3, no. 9, pp. 8596, 2017.

[13] M. Adedoyin and A. A. Adegoke, "Teenage prostitution-child abuse: A survey of Ilorin situation.” Afr. J. of Med. Sci., vol. 24, no. 1, pp. 27-31, 1995.

[14] D. M. Allen, “Why Don't Child Sex Abuse Victims Tell?” Psychology Today. 2012. [Online]. Available: https://www.psychologytoday.com/us/blog/matterpersonality/201210/why-dont-child-sex-abuse-victims-tell.
[15] L. M. Jones, D. Finkelhor, and J. Beckwith, "Protecting victims' identities in press coverage of child victimization,” Journal., vol. 11, no. 3, pp. 347-367, 2010.

[16] M. Bennett and K. Gillingham, "The role of self-focused attention in children's attributions of social emotions to the self," The J. of Gen. Psychol., vol. 152, no. 3, pp. 303-9, 1991.

[17] M. Bennett, “Children’s self-attribution of embarrassment,” British J. of Developm. Psychol., vol. 7, pp. 207-17, 1989.

[18] E. Deblinger, and M. K. Runyon, "Understanding and treating feelings of shame in children who have experienced maltreatment," Chi. Maltrea., vol. 10, pp. 364-76, 2005.

[19] D. Finkelhor, Child sexual abuse: new theory and research. New York: The Free Press, 1984.

[20] S. E. Ullman, "Social reactions to child sexual abuse disclosures: critical review,” J. of Child Sex. Abuse, vol. 12, no. 1, pp. 89-121, 2003.

[21] U. Pate, "Ethics and nation building in Nigeria," National Conference and Annual General Meeting of the Nigerian Institute of Public Relations, NIPR, Abuja, 2013.

[22] C. W. Duru, “Online Journalism and the Challenge of Ethics in Nigeria," Journal. and Mass Commun., vol. 6, no. 10, pp. 585-593, 2016

[23] Nigeria Press Council, "Code of ethics: Code of ethics for Nigerian journalists,” $2015 . \quad$ [Online]. Available: http://www.presscouncil.gov.ng/?page_id=281

[24] K. McBride, "Naming the accuser: discuss your verdict now," Poynter Online, Aug. 25, 2004. [Online]. Available: http://poynter.org/column.asp?id=53\&aid=70535.

[25] B. Steele, “Naming rape victims,” Poynter Online, Aug. 10, 2002. [Online] Available: http://www.poyn ᄀter.org/content/content_view.asp?id=4010.

[26] S. P. Winch, "On naming rape victims: how editors stand on the issue," presented at the Commission on the Status of Women, Association for Education in Journalism and Mass Com $\neg$ munication Annual Convention, Boston, MA, USA, Aug. 1991.

[27] M. Utor, M. (2009). "An appraisal of the impact of media ethics on the practice of journalism,” In Topics in the mass media and public relations practice in Nigeria, T. Keghku and B.E. Melladu, Eds. Makurdi: Aboki Publishers, 2009, pp. 123-135.

[28] M. Egbon, "Problems of ethics in the mass media," presented at the Nigerian Press Council National Workshop, Lagos, Nigeria, Apr. 9-12, 2006.

[29] S. Tsegyu, and E. S. Asemah, “An investigation of media practitioners' adherence to professional ethics in Minna, Nigeria,” Rev. of Commun. and Med. Stud., vol. 1, no. 1, pp. 11-20, 2014.

[30] J. I. Ojobor, Theories of mass communication in Teaching Mass Communication: a Multi-Dimensional Approach, Okunna, C.S., Ed. Enugu: New Generation Books, 2002. 